\title{
The Dominance and Influence of Positivism Paradigm on Judicial Decision Making
}

\author{
Tri Laksmi Indreswari ${ }^{1,}$, \\ ${ }^{1}$ Faculty of Law, Diponegoro University, 50275, Semarang, Indonesia
}

\begin{abstract}
The court plays a pivotal role in the Indonesian law enforcement. The judge is the key component of judicial process and how the judge`s paradigm will give impact on court decision making. Paradigm represents a worldview of judge when handling a case. This paper used double type of legal research, doctrinal and non-doctrinal. Doctrinal legal research is used to obtain the secondary data and non-doctrinal legal research is intended to obtain the primary data. The purpose of this paper is to describe the factual condition of the paradigm on judicial decision making and to explain the influence of positivism paradigm on judge's role. The result concludes that the judge`s paradigm still dominate by positivism paradigm and judge`s role is only applying the law.
\end{abstract}

\section{Introduction and literature review}

Courts plays a pivotal role in Indonesian law enforcement. The court actually as the main representation of law enforcement. In fact, Indonesian law enforcement is often critized in relation to the court process. The court decisions are often seen as not reflecting juctice but only prioritizing legal certainty. There are many court's decisions that attract public or media attention because they are not considered to be justice oriented.

In the court process, a judge has an important position in deciding the case [1]. There are several factors that influence judicial decision making. The main factor that considered influential in the court process is the judge`s paradigm. Paradigm represents a worldview of judge when handling a case. Therefore paradigm will guide the judge in examining, adjudicating and deciding on a case.

\subsection{Paradigm}

Thomas Samuel Kuhn describes that a paradigm is the set of common beliefs and agreements shared between scientist about how problems should be understood and addressed. [2] A paradigm may be viewed as a set of basic beliefs ( or metaphysics) that deals with an ultimates or the first principles. It represents a worldview that defines, for its holder, the nature of the "world", "the individual 's" place in it and the range of possible relationships to that world and its parts. Inquiry paradigms define for inquirers what it is they are about, and what falls

*Corresponding author: laksmiindreswari@yahoo.com 
within and outside the limits of legitimate inquiry. The basic beliefs that define inquiry paradigms can be summarized by the responses given by proponents of any given paradigm to three fundamental questions, which are interconnected in such a way that the answer given to anyone's question, taken in any order, constrains how the others may be answered :[3]

a. The ontological question : what is the form and nature of reality and therefore what is there that can be known about it;

b. The epistemological question : what is the the nature of the relationship between the knower or would be knower and what can be known;

c. The methodological : how can the inquirer (would-be knower) go about finding out whatever he or she believes can be known.

According to paradigm viewed as a set of basic beliefs, EG Guba and YS Lincoln defide it into 5 inquiry paradigms : Positivism, Postpositivsm, Critical Theory, Constructivism and Participator. [4]

\subsection{Judge`s decision making}

Sudikno Mertokusumo defines judge's decision as a statement by the judge, as a state official authorized and it aims to settle a case.[5] Related to the judge's decision making, there are two ways to asses : traditional and non traditional approaches. Traditional approach is a legal study and a judge`s decision based on normative point of view. In other hand, non traditional approach is a legal study and judge's decision based on multidiscipline optics. The legism and legal positivism are included in the traditional approach while legal realism and sociological jurisprudence are included in non traditional approach.

Furthermore, there are two grand theories of judging : legal realism and legal formalism. For legal formalist, legal rules and logical reasoning are central to judicial decision-making. In more extreme versions of legal formalism, legal rules are the Alpha and Omega - the beginning and the ending of judicial decision-making. On the other hand, legal realism views that judge decide what the law is.[6]

\section{Objectives of the study}

This paper has two aims. First aim is to describe the factual conditions of the paradigm on judicial decision making. Second aim is to analyze the influence of positivism paradigm on the judge`s role.

\section{Methodology}

Our analyses are based on doctrinal and non-doctrinal legal research. For this purpose, we use primary and secondary data. The primary data are obtained directly from some information sources and the secondary data is obtained from many literatures. We interviewed fifteen judges to get information related to the topic. In order to obtain as much useful information as possible, an in-depth interview technique is chosen.

\section{Discussion}

As a country that inherited the Dutch Law, Indonesian legal system is based on Civil Law system which emphasizes on codification. Therefore, the legal jurists of Civil Law system are basically based on the mainstream that law is written in the books. This Civil law`s mainstream actually indicates to the positivism. Positivism is based on the rational paradigm Auguste Comte who rejected metaphysics and other form of knowledge. Auguste Comte 
emphasizes that knowledge should not exceed the facts.[7] Marret Leiboff and Mark Thomas describe legal positivsm is an approach to legal theory which is concerned with posited law, that is law which has been laid down, or posited by intitutions like Parliamnet and the courts. This way looking at law takes law as it is and analyses it within its own terms. One central characteristic of legal positivism is the idea that law is separate from, though not necessarily unrelated to the ideas of morality or other ways of assessing the value of human activities. Legal Positivism distinguishes between the existence of law in other, and it's merit or demerit, that is, the moral value of the content of the law on other. So the legal positivist do not concern whether a law is good or bad.[8]

This paper begins by describing the factual conditions of judge's paradigm when handling a case. The result of the research shows that the paradigm of judge is still dominated by the positivisme paradigm. In the view of positivism paradigm, the law is seen to be something that contains the law completely. Generally, judge uses the written law as the main source when decide a case which is related to the Civil Law system. According to the legal tradition of Civil Law, codes and special legislation are recognized as the primary source of law [9].

The judicial decision-making process is a result of the conclusion reached on the basis of syllogism : the law is the major premise, the fact of the case is the minor premise and finally the conclusion is with logical reasoning. The judge`s decision-making based on the research indicates that judge derives a conclusion through deductive method. By applying a deductive method, a closed logic system requires the major premise as a determinant. With this condition, according to legal formalist, judges are essentialy "giant syllogism machines.[10] The law according to the positivism paradigm is defined as the normative law. Justice is what is stated in the written or nomative law. That is to say, law is an isolated field of interaction with many aspects such as moral, sociological, justice, etc.

Hart, one of the positivism philosophers emphasizes that law is a closed logical system. On the positivism paradigm way looking, law is a logical structure consisting of a complete and comprehensive rules. The law is made to be top-down by the legislative with the aim of regulating society. Therefore, judicial decision-making is generally based on the law which is made by the legislature.

Based on the research shows the practice of judicial decision-making is mostly dominated by positivism paradigm. Indeed this condition has implications on the judge`s role. The role of judge has to apply the law. In this point, according to Montesquieu, judge is often associated with " le juge est la bouche de la loi', the mouth of the law. The judges are described as subsumptie automat, not a law creator, but only apply the law. The function of judges are a mechanical one. [11] The dominance of positivism paradigm actually shows that the judge as a prisoner of the law.

The judges who responded to this research identified that they apply the law very strictly which aims for legal certainty. As we know, the main value of the positivist paradigm is the legal certainty. By applying the written law, a judge`s role is related to the legal certainty value oriented. Indeed legal certainty has several advantages but when the judge`s role is only applied to the law, it is obvious recognized that the judge`s lack of courage to make rule breaking when decide a case.

\section{Conclusion}

The judicial decision in practice is known as the result of the court process. In this court process, the judge is a central figure who is in charge to decide a case. There are several factors influencing the judicial decision-making. One of these factors which refer to the research shows that the judge`s paradigm is still dominated by the positivism paradigm. The judge uses the written law as the main source of law and based on a syllogism. The written law is seen as a complete and comprehensive rule so that the judge should apply it when 
decides a case. Indeed, this conditions have impact on judge`s role. The judge`s role is associated with mouth of the law or bouch de la loi.

\section{References}

1. E. Indarti, dlr 1, 1 Pp. 1-16 (2016)

2. T. Kuhn, The Structure of Scientific Revolutions (The University of Chicago Press, Chicago, 1962)

3. D. N. and L. YS, Handbookof Qualitative Research (Sage Publications, London, 1994)

4. D. N.and L. YS, Paradigmatic Controversies, Contradictions and Emerging Confluences, Revisited (Sage Publications, London, 2011)

5. S. Mertokusumo, Hukum Acara Perdata (LIberty, Yogyakarta, 1998)

6. V. Tumoris, "Legal Realism and Judicial Decision Making," Jurisprudence, no. ISSBN 2029-2058, (2012)

7. W. D. Putro, Kritik Terhadap Paradigma Positivisme Hukum. (Genta Publishing, Yogyakarta, 2011)

8. M. T. M. Leiboff, Legal Theories In Principle (lawbook.Co, New South Wales, 2004)

9. V. Fon, IRLE., 26, 4, Pp. 519-535 (2006)

10. J.J. Rachlinski, How Judges Make Decision (Elev. Int. Publ.2012)

11. J. H. Merrymen, The Civil Law Tradition An Introduction to the Legal System of Western Europe and Latin America (Stanford University Press, Stanfors, 2007) 